\title{
The effect of lead exposure of mice during preg- nancy on the concentration and motility of epididy- mal and testicular spermatozoa in offspring mature male mice
}

\author{
Al-Khfaji IN ${ }^{\mathrm{a}}$, Fakhrildin MB ${ }^{\mathrm{b}}$, Al-Ani IMc, Mangalo $\mathrm{HH}^{\mathrm{a}}$, Al-Obaidi SR \\ a Department of Biology, College of Science, Al-Mustansiriah University, Baghdad, IRAQ \\ b Department of In Vitro Fertilization and Embryo Transfer, Al-naharain Research Center for Biotechnology, \\ Al-Naharain University, Baghdad, IRAQ \\ c Department of BMS, Kulliyyah of Medicine, International Islamic University Malaysia, \\ Kuantan, MALAYSIA \\ d Department of Histopathology, College of Medicine, University of Baghdad, IRAQ
}

\begin{abstract}
Introduction: The objective of this study was to investigate the effects of lead on concentration and motility of spermatozoa recovered from epididymis and testes in mature male offspring whose mothers were exposed to different doses and concentrations of lead acetate during gestation period. Materials and Methods: Seventy two healthy mature female mice were divided into three major groups according to the number of injections involving 1, 2 and 3 injections. Each major group was subdivided into four minor groups according to the concentration dose of $(0,25,50$ and 100$) \mathrm{mg} / \mathrm{Kg}$ of lead acetate. Sperm concentration, percentage of motility and grade of activity were microscopically examined and statistically analyzed. Results: A significant reduction in the sperm functions were seen in relation to an increased in the number of injections and/or concentration of lead acetate dose as compared with the control groups. Conclusion: The toxic effects of lead acetate may interfere with spermatogenesis and metabolism of spermatozoa.
\end{abstract}

KEYWORDS: Lead acetate, Spermatozoa, Sperm motility, Epididymis, Testis.

\section{INTRODUCTION}

Historically, lead related diseases have been recognized by physicians Hippocrates and Nikander since more than two thousand years ago. ${ }^{1}$ Lead and it is salts were widely distributed and accumulated in the atmosphere, ${ }^{2}$ soil, rocks, ${ }^{3}$ deep marine sediments, ${ }^{4}$ and animal ${ }^{5}$ and plant $^{6}$ tissues. Most of the lead in our environment comes from gasoline used in our cars and from exposure to it when lead painted homes and other structures need to be repaired ${ }^{7}$ and from the industrial sources. ${ }^{8}$

By the early nineteenth century, the occupational lead poisoning had become a serious problem. Lead toxicity in workers in lead industries was observed; among those workers the infant mortality was high. ${ }^{9}$ Recently, there has been substantial interest in the potential adverse effects of exposure to environmen-

Corresponding author:

Dr. Imad Matloub Al-Ani

Department of Basic Medical science, Kulliyyah of Medicine, International Islamic University Malaysia, P.O. Box 141, 25710 Kuantan, Pahang, MALAYSIA. E-mail: imad_alani@yahoo.com tal hazardous chemicals on male reproductive system. ${ }^{10}$ Clinical attention has been focused upon the toxicity of lead on the peripheral and central nervous system and also in liver, kidney and the immune system. ${ }^{11}$

It is known that lead causes both acute and chronic poisoning depending on exposure length and blood level, the toxicity is manifested in various forms of gastrointestinal and neurological symptoms. ${ }^{12}$ Corpas et $a{ }^{13}$ showed that the lead exerts a wide range of adverse biological effects, and one of it is main targets is the performance of reproduction. In addition to impotence and sterility, lead may causes impairment of spermatogenesis ${ }^{14}$ and decreased ability to produce healthy spermatozoa in male workers exposed to lead compounds. ${ }^{15}$

It was documented that the chronic exposure to lead led to an increase in the level of blood lead concentration. This increment in blood lead level concentration was associated with reduced semen volume and density, total count of motile spermatozoa, progressive sperm motility and percentage of sperm viability ${ }^{16}$ and was associated with reduced concentration of androgen. ${ }^{17}$

The adverse effects of lead on sperm concentration in animals treated with different doses of lead salts were reported by a number of investigators, ${ }^{18,19}$ but none of these studies describe the effects of lead exposure during gestation on the offspring spermatozoa. In recent study, we described the 
morphological changes of the epididymal and testicular spermatozoa of mature male offspring mice whose mothers were exposed to various doses of lead acetate during gestation. ${ }^{20}$ Therefore, the purpose of the present study is to assess the toxic

effects of lead acetate injected throughout gestation period on concentration, percentage of motility and grade activity of testicular and epididymal spermatozoa recovered from offspring mature male mice.

\section{MATERIALS AND METHODS}

\section{Animals}

Seventy two healthy mature Swiss albino female mice ( 8 weeks old) were obtained from animal house of AlNaharain College of Medicine and kept under suitable environmental conditions (e.g. room temperature was maintained at $24+2{ }^{\circ} \mathrm{C}$ and exposure to 12 hours daylight). Vaginal smears were prepared to examine the regularity of at least three consecutive estrus cycles. During the estrus stage, the females mated males. After examination of vaginal plug to observe spermatozoa, the gestation period was started and considered the first day of pregnancy. ${ }^{21}$ The experimental animal protocol was conducted in compliance with humane animal care standards outlined in the National Institutes of Health Guide for the Care and Use of Laboratory Animals. The experimental study was approved by the University ethical committee.

\section{Experimental Design}

The female mice were divided into three major groups according to the number of injections (1,2 and 3). Each major group was further subdivided into four minor groups according to the quantity of dosage (Table I).

When male's offspring reach the period of sexual maturation (two months) they were killed by decapitation, testes and epididymis were taken and minced in two small Petri dishes containing $1 \mathrm{ml}$ of Earl's medium until the solution was homogenized.

\section{Microscopic analysis of the seminal fluid}

All slides were prepared for microscopical examinations from 40, 38, 34 and 34 offspring males where their mothers were injected with 0, 25, 50 and 100 $\mathrm{mg} / \mathrm{Kg}$ of lead acetate during gestation, respectively. A drop of spermatozoal suspension was placed on the slide and covered with cover-slide. Concentration of spermatozoa (spermatozoa/ml) was calculated from the mean number of spermatozoa in 10 microscopic fields under magnification of 40X. The mean number was multiplied by a factor of one million. ${ }^{22}$ Motile spermatozoa were counted as a percentage of observed total numbers of spermatozoa in 10 random microscopic fields at 40X magnification. Sperm grade activity was determined by using a scale of (0-5) as mentioned in details by Fakhrildin. ${ }^{23}$

\section{Statistics}

In addition to the standard methods to determine the mean, standard deviation and standard error of the mean (S.E.M.), one way analysis of variance (ANOVA)
Table I: The experimental design of the present study.

\begin{tabular}{ll} 
Dose & \multicolumn{3}{c}{ Number of treated females } \\
& $\begin{array}{lll}\text { (One } & \text { (Two } & \text { (Three } \\
\text { injection) at injections) at injections) at } \\
8^{\text {th }} \text { day of } & 8^{\text {th }} \text { and } 13^{\text {th }} & 8^{\text {th }} \cdot 13^{\text {th }} \text { and } \\
\text { gestation } & \text { days of } & 18^{\text {th }} \text { days of } \\
\text { period } & \text { gestation } & \text { gestation } \\
\text { period } & \text { period }\end{array}$
\end{tabular}

$\begin{array}{llll}0 & 6 & 6 & 6 \\ \text { (Control) } & & 6 & 6 \\ 25 \mathrm{mg} / \mathrm{kg} & 6 & 6 & 6 \\ 50 \mathrm{mg} / \mathrm{Kg} & 6 & 6 & 6\end{array}$

$\mathrm{mg} / \mathrm{Kg}$

was used to test the significant difference between treatments $(0,25,50$ and $100 \mathrm{mg} / \mathrm{Kg}$ of lead acetate). Also, when the analysis of variance was significant, multiple comparisons by improved Tukey's test were used to determine in which group of treatment the significant difference appeared. ${ }^{24}$

\section{RESULTS}

Epididymal and testicular sperm concentration

The concentration of epididymal and testicular spermatozoa for the control and treated groups are shown in the tables 2 and 3 respectively. These results certified significant $(p<0.05)$ and highly significant $(p<0.01)$ differences in the concentration of spermatozoa between treated groups as compared with its control groups.

As the number and quantity of dose was increased, there was a gradual reduction in the mean concentration of epididymal and testicular spermatozoa. The most remarkable reduction was obtained after three injections of lead acetate at dose $100 \mathrm{mg} / \mathrm{Kg}(24.00+$ 1.83 and $6.40+0.45$ respectively)(Table II \& III).

The three injections of $50 \mathrm{mg} / \mathrm{Kg}$ lead acetate had significantly reduced the concentration of epididymal spermatozoa as compared to one and two injections $(p<0.05)$. Similarly, significant differences $(p<0.01)$ in the testicular spermatozoa were seen between one injection of dose $25 \mathrm{mg} / \mathrm{Kg}$ and dose $50 \mathrm{mg} / \mathrm{Kg}$ when compared to the two and three injections of the same doses.

Percentage of epididymal and testicular sperm motility

All different doses of lead acetate induced a reduction in the percentages of epididymal sperm motility (Table IV). Non significant $(p>0.05)$ differences were reported in the percentage of motility of epididymal spermatozoa among one, two and three injections of dose $25 \mathrm{mg} / \mathrm{Kg}$ of lead acetate. Three injections of dose $50 \mathrm{mg} / \mathrm{Kg}$ of lead acetate has significantly $(p<0.05)$ reduced the percentage of epididymal sper- 
Table II: Epididymal sperm concentration (X 106 $/ \mathrm{ml}$ ) of mice born to mothers treated with different lead acetate concentrations and doses.

$\begin{array}{cccc}\text { Dose } & \begin{array}{c}\text { One } \\ \text { injection }\end{array} & \begin{array}{c}\text { Two } \\ \text { injections }\end{array} & \begin{array}{c}\text { Three } \\ \text { injections }\end{array} \\ \mathbf{0 ~ \mathrm { mg } / \mathrm { Kg }} & 53.5 & 51.8 & 60.2 \\ \text { (Control) } & \pm 1.5 & \pm 1.21 & \pm 1.13 \\ \mathbf{2 5} & 40.75 * & 40.76 * \# & 37.33 * \# \mathrm{~s} \\ \mathbf{m g} / \mathrm{Kg} & \pm 1.2 & \pm 1.42 & \pm 2.22 \\ \mathbf{5 0} & 35.36 * \mathrm{c} & 34.20 * \mathrm{c} & 28.69 * * * \mathrm{a} \mathrm{b} \\ \mathbf{M g} / \mathrm{Kg} & \pm 1.4 & \pm 1.38 & \pm 1.63 \\ \mathbf{1 0 0} & 32.50 * & 27.57 * * * & 24.00 * * * \\ \mathbf{m g} / \mathrm{Kg} & \pm 2.56 & \pm 2.76 & \pm 1.83\end{array}$

Table IV: Percentages of epididymal sperm motility of mice born to mothers treated with different lead acetate concentrations and doses

\begin{tabular}{|c|c|c|c|}
\hline Dose & $\begin{array}{c}\text { One } \\
\text { injection }\end{array}$ & $\begin{array}{c}\text { Two } \\
\text { injections }\end{array}$ & $\begin{array}{c}\text { Three } \\
\text { injections }\end{array}$ \\
\hline $0 \mathrm{mg} / \mathrm{Kg}$ & 53.1 & 62.6 & 57.2 \\
\hline (Control & 1.46 & 1.15 & 1.21 \\
\hline 25 & 49.43 & $49.15 * \#$ & $45.05 *$ \\
\hline $\mathrm{mg} / \mathrm{Kg}$ & 1.34 & 0.59 & 2.58 \\
\hline 50 & $49.18^{c}$ & $48.50 * \#$ & $43.15 * a$ \\
\hline $\mathrm{mg} / \mathrm{Kg}$ & 1.27 & 0.76 & 1.57 \\
\hline 100 & $45.90 * c$ & $44.71 * * * 5 \mathrm{c}$ & $\underset{b}{40.02}$ *a \\
\hline $\mathrm{mg} / \mathrm{Kg}$ & 0.67 & 0.98 & 0.71 \\
\hline
\end{tabular}

Table VI: Epididymal sperm grade activity of mice mothers treated with different lead acetate concentrations and doses.

\begin{tabular}{|c|c|c|c|}
\hline Dose & $\begin{array}{c}\text { One } \\
\text { injection }\end{array}$ & $\begin{array}{c}\text { Two } \\
\text { injections }\end{array}$ & $\begin{array}{c}\text { Three } \\
\text { injections }\end{array}$ \\
\hline $0 \mathrm{mg} / \mathrm{Kg}$ & 3.42 & 2.94 & 3.41 \\
\hline (Control) & \pm 0.1 & \pm 0.14 & \pm 0.07 \\
\hline 25 & $2.81 * \# c$ & $2.63 \# c$ & $2.10 * a b$ \\
\hline $\mathrm{mg} / \mathrm{Kg}$ & 0.08 & 0.07 & 0.2 \\
\hline 50 & $2.56 * \# c$ & $2.54 \# c$ & $1.96 * a b$ \\
\hline $\mathrm{Mg} / \mathrm{Kg}$ & \pm 0.05 & \pm 0.07 & \pm 0.08 \\
\hline 100 & $\begin{array}{l}2.17 * * * \\
\text { S b c }\end{array}$ & $1.76 * * * 5 a$ & $1.54 * a$ \\
\hline $\mathrm{mg} / \mathrm{Kg}$ & \pm 0.09 & \pm 0.13 & \pm 0.06 \\
\hline
\end{tabular}

Values are presented as mean \pm SEM.

*: Significantly $(P<0.05)$ different from its control.

**: Significantly $(P<0.05)$ different from $25 \mathrm{mg} / \mathrm{Kg}$ group.

$\$$ : Significantly $(P<0.05)$ different from $50 \mathrm{mg} / \mathrm{Kg}$ group.

\#: Significantly $(P<0.01)$ different from $100 \mathrm{mg} / \mathrm{Kg}$ group.

a: Significantly $(P<0.01)$ different from one injection.

b: Significantly $(P<0.05)$ different from two injections.

c: Significantly $(P<0.05)$ different from three injections.
Table III: Testicular sperm concentration (X 106 $/ \mathrm{ml})$ of mice born to mothers treated with different lead acetate concentrations and doses.

\begin{tabular}{|c|c|c|c|}
\hline Dose & One injection & $\begin{array}{c}\text { Two } \\
\text { injections }\end{array}$ & $\begin{array}{c}\text { Three } \\
\text { injections }\end{array}$ \\
\hline $0 \mathrm{mg} / \mathrm{Kg}$ & 16.2 & 18.3 & 17.3 \\
\hline (Control) & \pm 1.36 & \pm 0.84 & \pm 0.76 \\
\hline 25 & $14.06 \# 5 b c$ & $\underset{\mathrm{a}}{10.46}$ * & 9.33 * \# a \\
\hline $\mathrm{mg} / \mathrm{Kg}$ & \pm 0.41 & \pm 0.97 & \pm 0.97 \\
\hline 50 & $10.81 \Rightarrow * * b c$ & $\underset{a}{8.60}$ * & $8.03 * a$ \\
\hline $\mathrm{mg} / \mathrm{Kg}$ & \pm 0.4 & \pm 0.37 & \pm 0.43 \\
\hline $\begin{array}{c}100 \\
\mathrm{mg} / \mathrm{Kg}\end{array}$ & $\begin{array}{l}8.30 \ldots * \pi \\
\pm 0.74\end{array}$ & $\begin{array}{l}7.92 \text { * } \\
\pm 0.48\end{array}$ & $\begin{array}{l}6.40^{* * *} \\
0.45^{*}\end{array}$ \\
\hline
\end{tabular}

Table V: Percentages of testicular sperm motility of mice born to mothers treated with different lead acetate concentrations and doses.

$\begin{array}{cccc}\text { Dose } & \begin{array}{c}\text { One } \\ \text { injection }\end{array} & \begin{array}{c}\text { Two } \\ \text { injections }\end{array} & \begin{array}{c}\text { Three } \\ \text { injections }\end{array} \\ \mathbf{0 ~} \mathbf{~ m g} / \mathrm{Kg} & 41.7 & 43.4 & 42.5 \\ \mathbf{( C o n t r o l )} & \pm 0.95 & \pm 1.7 & \pm 1.7 \\ \mathbf{2 5} & 40.06 & 38.30 * & 37.44 \\ \mathbf{m g} / \mathrm{Kg} & \pm 1.34 & \pm 0.57 & \pm 1.74 \\ \mathbf{5 0} & 38.72 & 38.5 & 37.76 \# \\ \mathbf{m g} / \mathrm{Kg} & \pm 1.14 & \pm 1.78 & \pm 2.67 \\ \mathbf{1 0 0} & 36.30 * \mathrm{c} & 32.35 * * * & 29.02 * \mathrm{~s} \\ \mathbf{m g} / \mathrm{Kg} & \pm 0.8 & \pm 1.79 & \pm 1.17\end{array}$

Table VII: Testicular sperm grade activity of mice born to mothers treated with different lead acetate concentrations and doses.

\begin{tabular}{cccc} 
Dose & $\begin{array}{c}\text { One } \\
\text { injection }\end{array}$ & $\begin{array}{c}\text { Two } \\
\text { injections }\end{array}$ & $\begin{array}{c}\text { Three } \\
\text { injections }\end{array}$ \\
\hline $\mathrm{mg} / \mathrm{Kg}$ & 1.86 & 1.85 & 1.76 \\
(Control) & \pm 0.04 & \pm 0.08 & \pm 0.12 \\
25 & $1.85 \# \$ c$ & $1.83 \# \$ c$ & $\begin{array}{c}1.48 * \# \mathrm{~b} \\
\mathrm{~b}\end{array}$ \\
$\mathrm{mg} / \mathrm{Kg}$ & \pm 0.06 & \pm 0.09 & \pm 0.1 \\
50 & $1.40 * * *$ & $1.42 * * *$ & $1.39 * \#$ \\
$\mathrm{mg} / \mathrm{Kg}$ & \pm 0.07 & \pm 0.03 & \pm 0.05 \\
100 & $1.35 * * *$ & $1.18 * * \$ \mathrm{a}$ & $1.13 * * \$$ \\
$\mathrm{~b} / \mathrm{c}$ & \pm 0.09 & \pm 0.06 & \pm 0.06 \\
\hline
\end{tabular}


matozoa when compared to one and two injections of the same dose. However, the results of the present study observed that the most reduction in the percentage of motility of epididymal spermatozoa was obtained with three injections of dose $100 \mathrm{mg} / \mathrm{Kg}$ of lead acetate as compared to the other injections.

From the results in Table $\mathrm{V}$, an overall gradual decrease in the percentage of testicular sperm motility was seen with an increasing number and quantity of lead acetate doses. Within the doses of $25 \mathrm{mg} / \mathrm{Kg}$ and $50 \mathrm{mg} / \mathrm{Kg}$, no significant $(\mathrm{p}>0.05)$ differences were registered in the percentage of motility compared to control groups. In addition, the percentage of motility was not significantly $(p>0.05)$ reduced among one, two and three injections. Significant $(p<0.05)$ decrease was obtained after three consecutive injections of dose $100 \mathrm{mg} / \mathrm{Kg}$ of lead acetate as compared to its control groups.

\section{Epididymal and testicular sperm grade activity}

The variance analysis for epididymal sperm grade activity showed a significant $(p<0.05)$ difference among different doses as compared to its control groups, except for two injections of doses $25 \mathrm{mg} / \mathrm{Kg}$ and $50 \mathrm{mg} /$ $\mathrm{Kg}$ of lead acetate. Also, significant $(\mathrm{p}<0.01)$ reduction was noticed in the sperm grade activity of groups injected with one and two injections of $100 \mathrm{mg} / \mathrm{Kg}$ of lead acetate when compared to group injected with dose $25 \mathrm{mg} / \mathrm{Kg}$ of lead acetate. Three injections of $100 \mathrm{mg} / \mathrm{Kg}$ of lead acetate has statistically $(p<0.05)$ reduced the sperm grade activity as compared to one and two injections of doses $25 \mathrm{mg} / \mathrm{Kg}$ and $50 \mathrm{mg} / \mathrm{Kg}$ of lead acetate (Table VI).

Significant $(p<0.05)$ reduction in the grade activity of testicular sperm was reported among different doses and its control groups, except for one and two injections of dose $25 \mathrm{mg} / \mathrm{Kg}$ of lead acetate (Table VII). Also, significant $(p<0.05)$ differences were noted in the sperm grade activity of groups injected with one and two injections of doses $50 \mathrm{mg} / \mathrm{Kg}$ and $100 \mathrm{mg} / \mathrm{Kg}$ of lead acetate comparable to groups with dose 25 $\mathrm{mg} / \mathrm{Kg}$. Moreover, three injections of dose $100 \mathrm{mg} /$ $\mathrm{Kg}$ of lead acetate statistically $(\mathrm{p}<0.05)$ reduced the grade activity of testicular spermatozoa as compared to one injection of doses $25 \mathrm{mg} / \mathrm{Kg}$ and $50 \mathrm{mg} / \mathrm{Kg}$ of lead acetate as appeared in Table VII.

\section{DISCUSSION}

The results of this study showed a significant reduction in epididymal and testicular sperm concentration especially after two and three injections of doses 50 and $100 \mathrm{mg} / \mathrm{Kg}$ of lead acetate as compared to the control groups. This reduction may indicate an impairment of testicular sperm production. It was found that lead could disturb mitosis of spermatogenic cells and cause alterations in the proliferation of Sertoli cells, therefore an important decrease in the testicular sperm count within testes of adult offspring, and subsequently reduction of epididymal sperm count. ${ }^{13}$ It is well known that the major function of testes is spermatogenesis and hormone synthesis to produce spermatozoa. So when the testicular tissue is damaged by the toxic effects of lead, the process of spermatogenesis would be impaired. Hilderbrand et $\mathrm{al}^{25}$ reported inhibition of spermatogenesis in male rats orally exposed to lead at concentration of $50 \mathrm{ug} / \mathrm{dl}$. McGivern et $\mathrm{al}^{26}$ observed a decrease in the intra testicular sperm count in rats prenatally exposed to $0.1 \%$ lead acetate supplemented to drinking water and attributed that to the dysfunction of the Sertoli cells as these cells are responsible for the environment of germ cell proliferation and maturation. The effect of environmental lead on the male reproductive system has been considered as a major area of concern for several years by which the testicular spermatogenesis and spermatozoa within the epididymis are the major targets for lead effect to produce reproductive toxicity. ${ }^{27}$ A decrease in sperm concentration was observed in mature male rabbits given subcutaneous injections $(1.56 \mathrm{mg} / \mathrm{Kg})$ of lead acetate. ${ }^{28}$

The results of the present study showed a significant reduction in concentration, percentage of motility and grade activity of both epididymal and testicular spermatozoa of males prenatally exposed to one, two and three injections of $100 \mathrm{mg} / \mathrm{Kg}$ of lead acetate compared with their control. The sperm motility and grade activity are considered the most important criteria of semen quality and determinant of successful fertilization. ${ }^{23,29}$ The reduction in the motility may be due to the direct effect of lead on the physiology of the sperm cells and/or epididymis. ${ }^{30}$ Sokol et $\mathrm{al}^{31}$ suggested that lead exposure may lead to disruptions in the Gonadotropin-releasing hormone production and/or release in male rats with subsequent improvement to the processes of spermatogenesis.

It was reported that the main metabolic process which supplies energy for sperm motility is glycolysis under both aerobic and anaerobic conditions, and oxidative respiration was less efficient as a source of energy for sperm motility. Hence, lead toxicity may be affecting this process. ${ }^{32}$ Disturbance of energy metabolism has been suggested to play an important role in reducing sperm motility and blocking sperm maturation in fluoride, aluminum and lead treated animals. ${ }^{33,34}$ Lead acetate may inhibit spermatogenesis by a disturbance of the metabolic activities of the Sertoli cells. ${ }^{35}$ Plausible mechanisms of lead carcinogenicity include DNA damage and clastogenicity or inhibition of DNA synthesis or repair. Lead may also generate reactive oxygen species and oxidative damage to DNA. ${ }^{11}$

Recent electron microscopic studies demonstrated fine structural alterations of ovarian follicular cells after administration of cadmium chloride in female rabbits $^{36}$ and clear degenerative changes in Sertoli cells and different stages of spermatogenic cells in male rats treated with aluminum chloride. ${ }^{37}$ Further ultrastructural studies of the epididymis and testes of offspring whose mothers are treated with lead acetate are in progress. 


\section{CONCLUSION}

Lead acetate administration during gestation is capable of reaching embryonic tissue inducing toxic effect that may interfere with spermatogenesis and metabolism of spermatozoa after maturation of the offspring.

\section{REFERENCES}

1. Schwartz M. Occupational lead exposure: Health effects and remediation practices. Professional Safety 2001; 7:28-31.

2. Attenoux-Merono S, Pompil J, Botto A, Gri mal di F, Viala A. Urinary effects of metallic air pollutants on school children. Indoor Environ 1994; 3:35-8.

3. Menzer RE, Nelson JO. Water and soil pollut ants. In: Klaassen CD, Amdur MO, Doull J, eds. Casarett and Doull's toxicol ogy. The basic science of poi sons. New York: Macmillan Publishing Compa ny, 1986:825-56.

4. Khalaf AN, Al-Jafery AR, Khalid BY, Elias SS, Ishaq MW. The patterns of accumulation of some heavy metals in Barbus grypus (Heckle) from a polluted river. J Biol Sci Res 1985; 16:51-75.

5. Brogan GX. Effect of lead on specific organ system. In: Viccellio P, ed. Hand book of med ical toxicology. London: Little Brown and Company, 1993:145-150.

6. World Health Organization. Environmental health criteria. 3. Lead. Geneva, 1977.

7. Roychowdhury M. Environmental and Occupa tional lead exposure: Progress and perspec tive. Professional Safety 1998; 4:35-40.

8. Koren H, Bisesi M. Handbook of environmen tal health and safety: Principle and prac tice. Lewis Publishers, 2002.

9. Lin-Fu JS. Historical over view: Lead in the ancient world. In: Low level lead exposure: The clinical implication of current research. Needleman HL, ed. New York: Raven Press, 1980:5-7.

10. Graca A, Ramalho-Santos J, Pereira M. Ef fect of lead chloride on spermatogenesis and sperm parameters in mice. Asian $\mathrm{J}$ An drol 2004; 6:237-41.

11. Silbergeld EK, Waalkes M, Rice JM. Lead Car cinogen: Experimental evidence and mecha nisms of action. Am J Industrial Med 2000; 36:316-23.

12. Alomran $\mathrm{AH}$, Shleamoon $\mathrm{MN}$. Influence of chronic lead exposure on lymphocyte prolif erative response and immunoglobulin levels in a storage, battery workers. J Biol Sci Res 1988; 19:575-85.

13. Corpas I, Gaspar I, Martinez S, Codesal J, Candelas S. Testicular alteration in rats due to gestational and early lactational adminis tration of lead. Reprod Toxicol 1995; 9:30713.
14. Cullen MR, Kayne RD, Robins JM. Endocrine and reproductive dysfunction in men associ ated with occupational inorganic lead intoxi cation. Arch Environ Health 1984; 39:431-40.

15. Gennart JP, Buchet JP, Roels H, Ghyselen P, Lauwerys R. Fertility of male workers to cad mium, lead or manganese. Am J Epi demiol 1992; 135:1208-19.

16. Correia MA, Backers CE. Chelators and heavy metals intoxication. In: Katzung BG, ed. Basic and Clinical pharmacology. Cali fornia: Appleton and Lange, 1995:889-99.

17. Apostoli P, Kiss P, Porru S, Bonde JP, Van hoorne $M$. Male reproductive toxicity of lead in animals and humans. Occup Environ Med 1998; 55:364-74.

18. Coffigny H, Manaly AT, Lataillade GP, et al. Effect of lead poisoning of rats during preg nancy on the reproductive system and fertil ity of their offspring. Hum Exp Toxicol 1994; 13:241-246.

19. Wang L, Xun P, Zhao Y, et al. Effect of lead exposure on sperm concentrations and testes weight in male rats: A meta-regression analy sis. J Toxicol Environ Health 2008; 71:454-63.

20. Al-Ani IM, Al-Khafaji IN, Fakhrildin MR, Man galo $\mathrm{HH}, \mathrm{Al}$-Obaidi SR. The effect of lead ex posure of mice during pregnancy on the mor phology of epididymal and testicular sperma tozoa of their offspring. Int Med J Malaysia 2009;8. Available at http://iiumedic.com/ eimj. Accessed January 1, 2011.

21. Zarrow MX, Yochim JM, McCarthy JL. Experi mental endocrinology. A source book of basic techniques. New York: Academic Press, 1964: 24-37.

22. World Health Organization. Laboratory man ual for the examination of human semen and sperm-cervical mucus interaction. UK: Cam bridge University Press, 1999.

23. Fakhrildin MB. The impact of seminal fluid infections and treatment on sperm functions and fertilizing capacity in infertile patients: Materials and methods. Unpublished thesis, 2000.

24. Ott L. Multiple comparisons. In: An introduc tion to statistical methods and Data analy sis. Massachusetts: PWS-Kent Publishing Com pany, 1988:437-66.

25. Hilderbrand DC, Der R, Griffin WT, Fahim MS. Effect of lead acetate on reproduction. Am J Obstet Gynecol 1973; 115:1058-65.

26. McGivern RF, Sokol RZ, Berman NG. Prenatal lead exposure in the rat during the third week of gestation: Long-term behavioral, physiological and anatomical effects associ ated with reproduction. Toxicol Appl Pharma col 1991; 110:206-15.

27. Wadi SA, Ahmed G. Effect of lead on male reproductive system in mice. J Toxicol Envi ron Health 1999; 40:170-6. 
28. Moorman WJ, Skaggs SR, Clark JC, Simon SD Male reproductive effects of lead including species extrapolation for the rabbit model. Reprod Toxicol 1998; 12;333-46.

29. Lamirande E, Gagnon C. Human sperm hyper activation in whole semen and its association with low superoxide scaveng ing capacity in seminal plasma. Fertil Steril 1993; 59:1291-5.

30. Hinton BT, Dolt HM, Stechel BP. Measurement of motility of rat spermatozoa collected by micropuncture from different regions along the epididymis. J Reprod Fertil 1979; 55:161-7.

31. Sokol RZ, Wang S, Wan Y-J, et al. Long-term, low-dose exposure alters the Gonadotropinreleasing hormone system in the rat. Environ Health Prespective 2002; 110:671-874.

32. Makler A, Makler SE, Stoller J, Lissak A, Blu menfeld Z. Use of a sealed mini-chamber to investigate human sperm motility in real time under aerobic and anaerobic condi tion. Arch Androl 1992; 29:255-61.

33. Chinoy NJ, Momin R, Jhala D. Fluoride and aluminum induced toxicity in mice epididymis and its mitigation by vitamin C. Fluoride 2005; 38:115-21.
34. Liu H, Niu R, Wang J, et al. Changes caused by fluoride and lead in energy metabolic enzyme activities in the reproductive system of male offspring rats. Fluoride 2008; 41:18491.

35. Batarseh LI, Welsh MJ, Brabec MJ. Effect of lead acetate on Sertoli cell lactate produc tion and protein synthesis in vitro. Cell Biol Toxicol 2004; 2:283-92.

36. Massanyi P, Uhrin V, Toman R, et al. Ultra structural changes of ovaries in rabbits following cadmium administration. Acta Vet Brno 2005; 74:29-35.

37. Khattab FKI. Histological and ultrastructur al studies on the testis of rat after treatment with aluminum chloride. Australian J Basic Appl Sci 2007; 1:63-72. 